\title{
An in planta induced gene of Phytophthora infestans codes for ubiquitin
}

\author{
Corné M.J. Pieterse, Eddy P. Risseeuw and Leen C. Davidse \\ Department of Phytopathology, Wageningen Agricultural University, P.O. Box 8025, 6700 EE \\ Wageningen, Netherlands
}

Received 15 October 1990; accepted in revised form 17 June 1991

Key words: differential screening, Oomycetes, Phytophthora infestans, polyubiquitin gene, potato late blight, ubiquitin

\begin{abstract}
An in planta induced gene of Phytophthora infestans (the causal organism of potato late blight) was selected from a genomic library by differential hybridization using labelled cDNA derived from poly(A) + RNA of $P$. infestans grown in vitro and labelled cDNA made from potato- $P$. infestans interaction poly(A) + RNA as probes. Sequence analysis showed that the gene codes for ubiquitin, a highly conserved protein which plays an important role in several cellular processes. The structure of the polyubiquitin gene (designated $u b i 3 R$ ) is consistent with the structure of other known polyubiquitin genes. It consists of three repeats in a head-to-tail arrangement without intervening sequences, each encoding a ubiquitin unit of 76 amino acids. The last ubiquitin unit is followed by an extra asparagine residue at the carboxy-terminal end. Northern and Southern blot analyses revealed that the polyubiquitin gene is a member of a multigene family, all genes of which show induced expression in planta.
\end{abstract}

\section{Introduction}

Potato late blight caused by the fungus Phytophthora infestans (Mont.) de Bary (Oomycetes) is one of the most important diseases of potato. Leaves and tubers of susceptible cultivars become readily infected by this pathogen. The fungus spreads rapidly through the plant tissue causing a destructive necrosis. Resistance to late blight in potato can be based on either a single gene or multiple genes. In general, single-gene-based resistance, governed by the so-called R genes, is characterized by a hypersensitive response resulting in a rapid cell death of invaded cells. Multiple-gene-based resistance is characterized by a low infection efficiency, slow tissue colonization and low sporulation rate. R-gene-mediated resistance is commercially not attractive because it becomes rapidly ineffective due to the appearance of new virulent strains of the fungus. Breeding efforts, therefore, aim at introducing durable multiple-gene-based resistance into commercial potato cultivars. The physiological basis of this type of resistance is hardly understood and, as a

The nucleotide sequence data reported will appear in the EMBL, GenBank and DDBJ Nucleotide Sequence Databases under the accession number X55717. 
consequence, breeders have to rely on empirical methods.

It can be assumed that the establishment of a pathogenic relation between the potato plant and $P$. infestans involves the mutual interference in cellular processes of each partner. Defence responses of host tissue being colonized (e.g. accumulation of pathogenesis-related (PR) proteins and induction of enzymes of the phenylpropanoid pathway) are relatively well studied $[9,10,16$, 25 ], but nothing is known about changes in metabolism of pathogen in response to the host. In other plant-microbe interactions - pathogenic (e.g. dicots-Agrobacterium tumefaciens and peaFusarium solani f.sp. pisi) as well as symbiotic interactions (legumes-Rhizobium spp.) - signal molecules originating from the host have been characterized which induce expression of genes involved in establishing the interaction $[24,41$, 48]. It is therefore tempting to suggest also in the potato- $P$. infestans interaction that host factors induce physiological responses in the pathogen which are necessary for pathogenesis and which are mediated by pathogenicity genes. In view of this, both defence responses of the host and the degree to which pathogenicity genes are activated in the pathogen ultimately determine speed and efficiency of the infection and colonization process and the intensity of sporulation. The result of these processes is reflected in the degree of durable resistance. The identification and characterization of in planta induced genes of $P$. infestans therefore will lead to a better understanding of the molecular basis of both pathogenicity of the fungus and durable resistance of the host.

The present study concerns the characterization of a $P$. infestans gene which was isolated from a genomic library by differential screening. The probes used were cDNA made from poly(A) ${ }^{+}$ RNA of $P$. infestans grown in vitro and cDNA synthesized on poly(A) ${ }^{+}$RNA isolated from potato leaves infected with a compatible $P$. infestans race. This gene, designated $u b i 3 R$, codes for ubiquitin, one of the most conserved proteins known to date. The significance of the in planta induced expression of this gene will be discussed.

\section{Materials and methods}

Culturing of Phytophthora infestans and inoculation of potato leaves

Strain 88069 of $P$. infestans (Mont.) de Bary (A1mating type, race 1.3.4.7) was isolated from a naturally infected tomato plant in the summer of 1988 and was maintained on rye-agar medium containing $2 \%$ sucrose [8]. Liquid cultures in $25 \mathrm{ml} \mathrm{Henniger} \mathrm{synthetic} \mathrm{medium} \mathrm{[21]} \mathrm{were} \mathrm{ini-}$ tiated from zoospores obtained from 2-week-old cultures on rye-sucrose agar at a concentration of $2 \times 10^{4}$ zoospores $/ \mathrm{ml}$. Cultures were incubated for 14 days at $20^{\circ} \mathrm{C}$ to obtain mycelium for DNA and RNA extractions.

Leaves of the potato cultivar 'Ajax', which carries the R3 gene for late blight resistance, were inserted in florist's foam oases saturated with water and inoculated with $P$. infestans by spraying a sporangial suspension $\left(5 \times 10^{5}\right.$ sporangia/ $\mathrm{ml}$ ) on the axial side of the leaflets. After inoculation, the leaves were incubated at $18{ }^{\circ} \mathrm{C}$ at $100 \%$ RH in plastic boxes with a transparent lid under cool fluorescent light for $16 \mathrm{~h}$ per day. As a control, uninoculated leaves were treated in the same way. Under these conditions the symptoms of the late blight disease develop from small necrotic lesions, which are first visible $24 \mathrm{~h}$ after inoculation, to completely 'water-soaked' leaves on day 3. During this period leaves were collected for RNA isolation. Four days after inoculation the fungus sporulates extensively. Secondary infections by necrotrophic bacteria prohibit the isolation of good-quality RNA in this stage.

\section{Isolation of genomic DNA and construction of a genomic library}

Genomic DNA of $P$. infestans was isolated from mycelium grown in liquid culture. Mycelium (10 g fresh weight) was ground in liquid nitrogen to a fine powder and mixed in $5 \mathrm{ml}$ of extraction buffer (200 mM Tris- $\mathrm{HCl}$ pH 8.5, $250 \mathrm{mM} \mathrm{NaCl}$, $50 \mathrm{mM}$ EGTA, $0.8 \%$ (w/v) tri-isopropylnaphthalene sulphonic acid (TNS) and $0.48 \%$ (w/v) 4 aminosalicylic acid) per gramme of mycelium and incubated at $55^{\circ} \mathrm{C}$ for $5 \mathrm{~min}$. The mixture was 
extracted once with 0.6 volume of water-saturated phenol $\left(55^{\circ} \mathrm{C}\right)$. The water phase was then extracted once with an equal volume of phenol/ chloroform/isoamyl alcohol (25:24:1) and once with an equal volume of chloroform/isoamyl alcohol (24:1)). The DNA was precipitated with 0.6 volume of 2-propanol, dissolved in $\mathrm{T}_{10} \mathrm{E}_{1}(10 \mathrm{mM}$ Tris- $\mathrm{HCl} \mathrm{pH}$ 8.0, $1 \mathrm{mM}$ EDTA) and further purified by $\mathrm{CsCl}$ gradient centrifugation [28].

A genomic library was constructed in the replacement vector $\lambda$ EMBL3 [15], according to Frischauf [14] with minor modifications. Highmolecular-weight DNA was partially digested with Sau3AI and fragments of 15 to $23 \mathrm{~kb}$ were isolated after centrifugation on a $10-40 \%$ sucrose gradient. Of these fragments $300 \mathrm{ng}$ was ligated to $250 \mathrm{ng}$ of $\lambda$ EMBL3 Bam HI arms (Promega). Packaging of the ligated DNA, using the Packagene in vitro packaging system of Promega, was performed according to the manufacturer's instructions.

\section{Isolation of RNA and poly $(A)^{+} R N A$ and prepara- tion of labelled $C D N A$ probes}

Total RNA was prepared from mycelium of $P$. infestans grown in liquid cultures and from colonized leaflets (interaction RNA) using the guanidine hydrochloride RNA extraction method as described by Logemann et al. [27]. To check for integrity of RNA, the RNA was electrophoresed in a $1.5 \%$ agarose-TBE $(89 \mathrm{mM}$ Tris- $\mathrm{HCl}$, $89 \mathrm{mM}$ boric acid, $2 \mathrm{mM}$ EDTA) gel containing $0.5 \mu \mathrm{g} / \mathrm{ml}$ ethidium bromide. Poly(A) ${ }^{+}$RNA was isolated by oligo(dT)-cellulose chromatography as described by Maniatis et al. [28]. First-strand cDNA with a specific activity of ca. $1-2 \times 10^{8}$ $\mathrm{cpm} / \mu \mathrm{g}$ was prepared from $1 \mu \mathrm{g}$ poly $(\mathrm{A})^{+} \mathrm{RNA}$ as described by Sargent [39] using M-MLV reverse transcriptase (Gibco BRL) and oligo(dT) to prime the synthesis reaction.

\section{Differential screening, subcloning and sequencing}

The genomic library was plated on a recombinant deficient Escherichia coli host, strain MB406 (sup $\mathrm{E}, r e c \mathrm{~B} 21, \operatorname{rec} \mathrm{C} 22, s b c \mathrm{~B} 15, h f l \mathrm{~A}, h f l \mathrm{~B}, h s d \mathrm{R}^{-}$ ), which enables the propagation of a non-biased genomic library [49]. Four replica filters of the genomic library were made on Hybond- $\mathrm{N}^{+}$ membrane (Amersham) according to the instructions of the manufacturer. The library was differentially hybridized in duplicate at high stringency in hybridization mix containing $5 \times \mathrm{SSC}(750 \mathrm{mM}$ $\mathrm{NaCl}, 75 \mathrm{mM}$ sodium citrate), $5 \times$ Denhardt's solution $(0.1 \%(\mathrm{w} / \mathrm{v})$ Ficoll, $0.1(\mathrm{w} / \mathrm{v})$ polyvinylpyrrolidone, $0.1 \%(\mathrm{w} / \mathrm{v})$ BSA (fraction $\mathrm{V})$ ), $0.5 \%$ SDS and $100 \mu \mathrm{g} / \mathrm{ml}$ calf thymus DNA at $65^{\circ} \mathrm{C}$ for $16 \mathrm{~h}$ using as probes labelled cDNA $\left(10^{7} \mathrm{cpm}\right)$ derived from poly $(\mathrm{A})^{+}$RNA of the fungus grown in vitro, and labelled cDNA $\left(10^{7} \mathrm{cpm}\right)$ derived from interaction $\operatorname{poly}(\mathrm{A})^{+}$ RNA (3 days after inoculation). The filters were washed in $2 \times \mathrm{SSC} / 0.5 \% \mathrm{SDS}$ at $65^{\circ} \mathrm{C}$ and exposed to Kodak X-Omat S film for 2-7 days at $-80{ }^{\circ} \mathrm{C}$. The selected plaques were purified by a second round of differential hybridization as described above.

DNA from the selected lambda clone was digested with several restriction enzymes and separated on a $0.8 \%$ agarose-TBE gel. Following electrophoresis, the DNA was transferred to Hybond- $\mathrm{N}^{+}$membrane (Amersham) by capillary transfer [28] and hybridized at high stringency $\left(65^{\circ} \mathrm{C}\right)$ as described above using ${ }^{32} \mathrm{P}$-labelled interaction cDNA as probe. The membrane was washed in $2 \times \mathrm{SSC} / 0.5 \% \mathrm{SDS}$ at $65^{\circ} \mathrm{C}$ and exposed to Kodak X-AR film for $24 \mathrm{~h}$ at $-80{ }^{\circ} \mathrm{C}$. The hybridizing Sst I fragment was subcloned into pTZ19U using standard techniques [28] which resulted in the plasmid pUB-S (Fig. 1B). Both strands of overlapping subclones of pUB-S were sequenced by the dideoxy chain termination method [38] using a sequencing system (Promega) for sequencing on double-stranded DNA. For analysing the sequence data and to screen the EMBL Data Library [20] and the GenBank databank [5], the Sequence Analysis Software Package, Version 6.0, of the Genetics Computer Group (GCG) of the University of Wisconsin was used. 
a

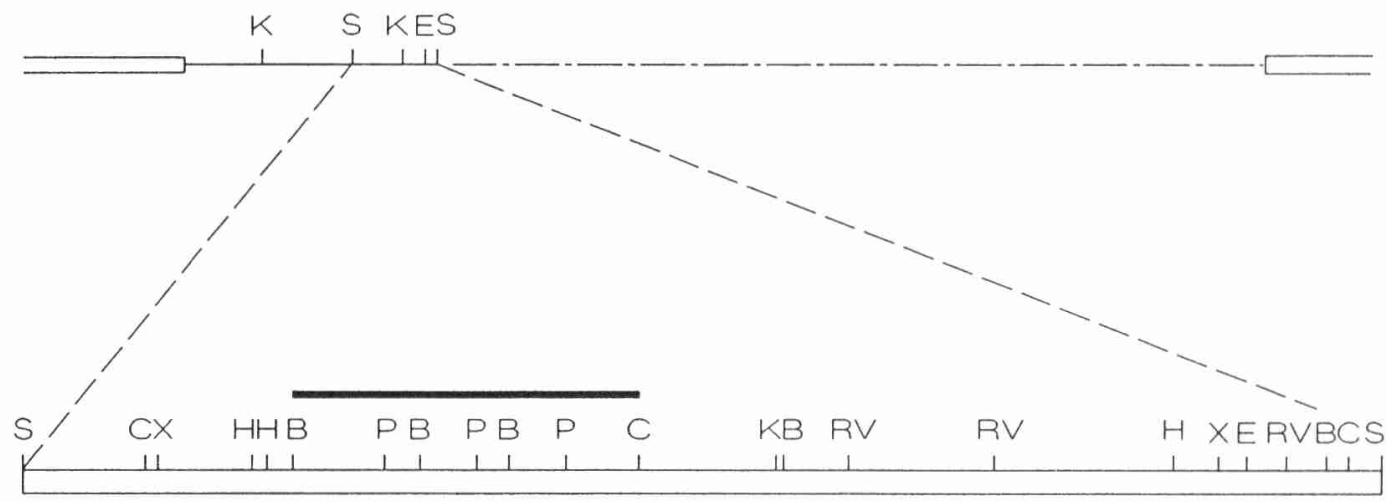

C

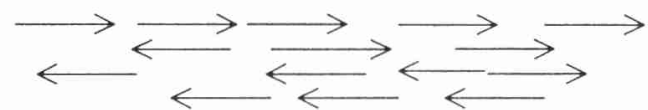

$200 \mathrm{bo}$

Fig. 1.a. Lambda clone DHCl (incomplete restriction map). b. Restriction map of the $3.2 \mathrm{~kb} \mathrm{Sst} \mathrm{I}$ insert of pUB-S. The closed bar indicates the approximate location of the coding region of the differentially expressed gene as determined by Southern hybridization using labelled interaction cDNA as probe. c. The sequencing strategy is indicated by arrows. B, Bgl II; C, Cla I; E, Eco RI; H, Hind III; K, Kpn I; P, Pvu II; S, Sst I; X, Xho I; RV, Eco RV.

Southern blot analysis of genomic Phytophthora infestans $D N A$

Genomic DNA $(10 \mu \mathrm{g})$ of P. infestans was digested with Kpn I, Eco RI, Bam HI, Hind III, and Sst $\mathrm{I}$ and size-separated on a $0.7 \%$ agarose-TBE gel. Following electrophoresis, the DNA was transferred to Hybond- ${ }^{+}$membrane (Amersham) by capillary transfer and hybridized at high stringency $\left(65^{\circ} \mathrm{C}\right)$ as described above to the two ${ }^{32}$ P-labelled 228 bp $P v u$ II fragments from the $u b i 3 R$ coding region (Fig. 1). Probe was made by random primer labelling using Promega's Primea-Gene labelling kit. The blot was washed in $0.5 \times \mathrm{SSC} / 0.1 \% \mathrm{SDS}$ at $65{ }^{\circ} \mathrm{C}$ and exposed to Kodak X-Omat $\mathrm{S}$ film for $16 \mathrm{~h}$ at $-80^{\circ} \mathrm{C}$.

Northern blot analysis and primer extension of $\operatorname{poly}(A)^{+} R N A$

For northern blot analysis, $15 \mu \mathrm{g}$ of total RNA was denatured and electrophoresed on a $1.5 \%$ agarose-formaldehyde denaturing gel as de- scribed by Maniatis et al. [28]. Following electrophoresis, the RNA was transferred to Hybond$\mathrm{N}^{+}$membrane (Amersham) by capillary transfer and hybridized at high stringency $\left(65^{\circ} \mathrm{C}\right)$ as described above using the two ${ }^{32} \mathrm{P}$-labelled $228 \mathrm{bp}$ $P v u$ II fragments from the coding region of $u b i 3 R$ as probe (Fig. 5A). The blot was washed in $0.5 \times \mathrm{SSC} / 0.1 \%$ SDS at $65{ }^{\circ} \mathrm{C}$ and exposed to Kodak X-Omat $\mathrm{S}$ film for 2 days at $-80^{\circ} \mathrm{C}$. Probe was then removed by immersing the membrane in a solution of boiling $0.1 \%$ SDS for $5 \mathrm{~min}$. The blot was rehybridized as described above using a gene-specific probe from the upstream region of the $u b i 3 R$ gene (Fig. 5B). The genespecific upstream DNA fragment was generated from $\mathrm{pUB}-\mathrm{S}$ by $\mathrm{PCR}$ using a primer (5'GGTTGCCTCGGTTTATG-3') complementary to the sequence at position -2 to -19 relative to the ATG start codon in the $u b i 3 R$ gene and the pUC/M13 sequencing primer (5'-GTTTTCCCAGTCACGAC-3' complementary to a sequence in the vector. The reaction mixture $(100 \mu \mathrm{l})$ contained $10 \mathrm{ng}$ pUB-S, $120 \mathrm{ng}$ of each primer, $0.2 \mathrm{mM}$ dNTPs and 2 units of AmpliTaq 
DNA polymerase (Perkin Elmer Cetus) in Taq polymerase buffer $(10 \mathrm{mM}$ Tris- $\mathrm{HCl} \mathrm{pH} 8.3$, $50 \mathrm{mM} \mathrm{KCl}, 1.5 \mathrm{mM} \mathrm{MgCl} 2,0.001 \%$ gelatin). Amplification was performed in a DNA Thermal Cycler in 18 cycles of $30 \mathrm{~s}$ at $94{ }^{\circ} \mathrm{C}, 30 \mathrm{~s}$ at $45^{\circ} \mathrm{C}$ and $90 \mathrm{~s}$ at $72{ }^{\circ} \mathrm{C}$. The $799 \mathrm{bp}$ PCR product was labelled with ${ }^{32} \mathrm{P}$-dATP by random primer labelling as described above. After hybridization and exposure, the blot was again deprobed and rehybridized, now using as probe the $2.8 \mathrm{~kb} P_{\text {st }} \mathrm{I}$ insert from pSTA31 containing the constitutively expressed actin (actA) gene of $P$. infestans [46] (Fig. 5C).

To map the $5^{\prime}$ end of the $u b i 3 R$ transcript, an oligonucleotide (5'-GTTGCCTCGGTTTATGAG-3') complementary to the sequence at position -2 to -19 relative to the ATG start codon was labelled with ${ }^{32} \mathrm{P}$ at its $5^{\prime}$ end using $\mathrm{T}_{4}$ polynucleotide kinase (Promega) according to the manufacturer's instructions. Labelled primer $(5 \mathrm{ng})$ was annealed to $3 \mu \mathrm{g}$ of $\operatorname{poly}(\mathrm{A})^{+}$RNA isolated from in vitro grown $P$. infestans mycelium and from uninoculated potato leaves as a control. Extension of the primer was performed in a reaction mixture $(25 \mu \mathrm{l})$ containing 400 units $\mathrm{M}$ MLV reverse transcriptase (Gibco BRL), $50 \mathrm{mM}$ Tris- $\mathrm{HCl} \mathrm{pH} 8.3,75 \mathrm{mM} \mathrm{KCl}, 10 \mathrm{mM}$ DDT, $3 \mathrm{mM} \quad \mathrm{MgCl}_{2}, \quad 0.1 \mu \mathrm{g} / \mu \mathrm{l}$ nuclease-free BSA, $200 \mu \mathrm{M}$ of each dNTP as $37^{\circ} \mathrm{C}$ for $45 \mathrm{~min}$. The primer extension products were analysed by electrophoresis on a polyacrylamide gel $(89 \mathrm{mM}$ Tris$\mathrm{HCl}, 89 \mathrm{mM}$ boric acid, $2 \mathrm{mM}$ EDTA, $8 \mathrm{M}$ urea, $5.7 \%$ acrylamide, $0.3 \%$ bisacrylamide) and detected by autoradiography.

\section{Results}

Selection of in planta induced Phytophthora infestans genes from a genomic library and mapping of one of these genes on the selected lambda clone

As calculated from microfluorometric determinations of nuclear DNA content [45], the haploid genome length of $P$. infestans is approximately $2.7 \times 10^{8}$ bp. In order to achieve a $99 \%$ probability of having any DNA sequence represented in the library, 80000 recombinant plaques were screened. Differential screening of the genomic library with fungal and interaction cDNA is performed under non-saturating conditions. Under these conditions the intensity of each obtained signal corresponds with the abundancy of a particular cDNA in the probe. A stronger signal obtained after hybridization with interaction cDNA as compared to the signal obtained after hybridization with fungal cDNA indicates a higher abundance of those cDNAs which are complementary to the DNA in the hybridizing lambda clone. Since the filters are hybridized with equal amounts of labelled cDNA, the procedure even underestimates the difference in abundance because the quantity of fungus-derived cDNA present in the interaction cDNA probe is much less than in the fungal cDNA probe. Thirteen plaques gave a relatively strong signal after hybridization with labelled interaction cDNA and a relatively weak or no signal after hybridization with labelled cDNA of the fungus grown in vitro. Approximately fifty additional plaques gave comparable signals after hybridization with both cDNA probes. One of the strongly differential hybridizing plaques (DHC1) was purified after a second round of differential hybridization. Southern analysis of various restriction fragments of DHC1 with interaction CDNA as probe revealed a strongly hybridizing $S s t$ I fragment of $3.2 \mathrm{~kb}$. This fragment containing a putative in planta induced gene was subcloned in pTZ19U and from the obtained plasmid pUB-S a restriction map was constructed. The approximate location of the coding region of the differentially expressed gene (closed bar in Fig. 1) was determined by Southern blot analysis using interaction cDNA as probe.

\section{Differentially expressed gene codes for polyubiquitin}

Several fragments of the $3.2 \mathrm{~kb}$ Sst I insert of pUB-S were subcloned and the sequence of $1632 \mathrm{nt}$ (nucleotides) was determined by dideoxy sequencing on both strands of various overlapping clones (Fig. 2). The sequencing strategy is 

$-750$
$-730$
$-710$
$-690$

GAGCTCCTTCATACGCCCGCGAAGACGGCTCACAAAGTCACCAATGTCCCCTAGACTCTGCTCGTCCGGAAAGTTTCGGT

$\begin{array}{llll}-670 & -650 & -630 & -610\end{array}$

TGATGAACTCGCGCGCATCGAACTCAGGTCGGTCCAACACGTCCTCCGAGGGCAAAACCTGTACATGAGACGTTGGTGAG
$-590$
$-570$
$-550$
$-530$

ACCTGGCAGCCAGCTTGAAACAGGACTGCAACACGAGGAAGATACTTTGGCTAGCGTGTCCTCCACGTTCTGAGGGAGCT
$-510$
$-490$
$-470$
$-450$

TCAATGCGCTTCCATCGCCGTCGCTGTACTCGCTGGCTCTGGCCGACGACGAGCCACGACGCAGTAATCGATCCATTT"IC
$-430$
$-410$
$-390$
$-370$

GACTCTTTTGAAGCTCGAGGATGACATATGATGGGATATTTGATTTATGTTAGAAGATAGGACTCTCGAAATATTGTAAC $-350$

$-330$

$-310$ $-290$

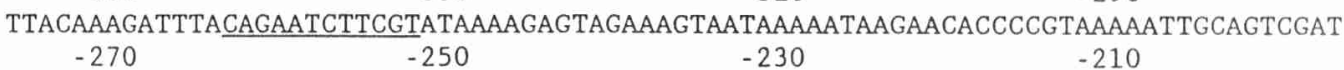

TTCTTACAATCTGGATTCAGCTTGTGATACCGGTAGCAAGGGGGGTATCACCTGCTGTTTATTTATTTCGCAAATTTTAT $\begin{array}{llll}-190 & -170 & -150 & -130\end{array}$

TCTGTGCGGGGAAGCTTTCGGCTGATAATCCTCTTTTCTCAAATCGAGAAGCTTCGTTTCAGTATGCCTACATCAACCTG $-110 \quad-90 \quad-70 \quad-50$

AGAACAAGGGTGGCCTTATCCCTTCCCCTCGGTAAGATCTATCGCTTCGAGCGCCTCCTTTGCTCÅTTTTCCATTTTGAG $\begin{array}{llll}-30 & -10 & +1 & 10\end{array}$

CGGAAACACTCAAGCACTCTCATAAACCGAGGCAACTATGCAGATTTTCGTGAAGACTTTGACCGGCAAGACGATCACGC $\begin{array}{lllllllllllllllll}50 & 70 & M^{1} & \text { Q } & \text { I } & \text { F } & \text { V } & \text { K } & \text { T } & \text { L } & \text { T } & \text { G } & \text { K } & \text { T } & \text { I } & \text { T } & \text { L }\end{array}$ TGGACGTGGAGCCTTCGGACTCGATCGACAACGTCAAGCAAAAAATTCAGGACAAGGAAGGCATCCCTCCTGACCAGCAG

$\begin{array}{lllllllllllllllllllllllllll}\mathrm{D} & \mathrm{V} & \mathrm{E} & \mathrm{P} & \mathrm{S} & \mathrm{D} & \mathrm{S} & \mathrm{I} & \mathrm{D} & \mathrm{N} & \mathrm{V} & \mathrm{K} & \mathrm{Q} & \mathrm{K} & \mathrm{I} & \mathrm{Q} & \mathrm{D} & \mathrm{K} & \mathrm{E} & \mathrm{G} & \mathrm{I} & \mathrm{P} & \mathrm{P} & \mathrm{D} & \mathrm{Q} & \mathrm{Q}\end{array}$ $130 \quad 150 \quad 170 \quad 190$

CGTCTGATCTTCGCTGGTAAGCAGCTGGAGGACGGCCGCACGCTGAGCGACTACAACATCCAGAAGGAGTCTACGCTTCA

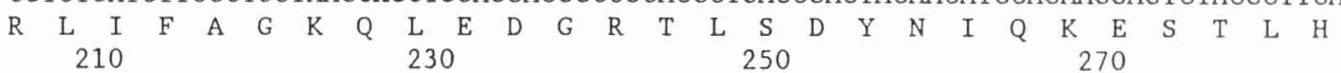
CCTGGTGCTTCGCCTGCGTGGTGGCATGCAGATCTTTGTGAAGACTTTGACCGGCAAGACGATCACGCTGGACGTGGAGC

$\begin{array}{lllllllllllllllllllllllllll}\mathrm{L} & \mathrm{V} & \mathrm{L} & \mathrm{R} & \mathrm{L} & \mathrm{R} & \mathrm{G} & \mathrm{G} & \mathrm{M}^{2} & \mathrm{Q} & \mathrm{I} & \mathrm{F} & \mathrm{V} & \mathrm{K} & \mathrm{T} & \mathrm{L} & \mathrm{T} & \mathrm{G} & \mathrm{K} & \mathrm{T} & \mathrm{I} & \mathrm{T} & \mathrm{L} & \mathrm{D} & \mathrm{V} & \mathrm{E} & \mathrm{P}\end{array}$ $\begin{array}{lrrrrrrr}290 & 310 & 330 & & & & & \end{array}$

CTTCAGACTCGATCGACAACGTCAAGCAAAAAATTCAGGACAAGGAAGGCATCCCTCCTGACCAACAGCGTCTGATCTTC

$\begin{array}{lllllllllllllllllllllllllll}\mathrm{S} & \mathrm{D} & \mathrm{S} & \mathrm{I} & \mathrm{D} & \mathrm{N} & \mathrm{V} & \mathrm{K} & \mathrm{Q} & \mathrm{K} & \mathrm{I} & \mathrm{Q} & \mathrm{D} & \mathrm{K} & \mathrm{E} & \mathrm{G} & \mathrm{I} & \mathrm{P} & \mathrm{P} & \mathrm{D} & \mathrm{Q} & \mathrm{Q} & \mathrm{R} & \mathrm{L} & \mathrm{I} & \mathrm{F} \\ 370 & & & & & & 390 & & & & & & 410 & & & & & & \end{array}$

GCTGGTAAGCAGCTGGAGGACGGCCGTACGCTGAGCGACTACAACATCCAGAAGGAGTCAACGCTTCATCTGGTGCTTCG

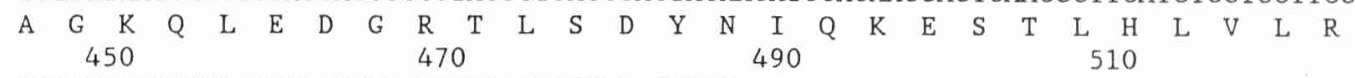
CCTGCGTGGTGGCATGCAGATCTTTGTGAAGACTTTAACTGGCAAGACGATCACGCTGGACGTGGAGC TTCAGACTCGA $\begin{array}{llllllllllllllllllllllllllllllllll}\mathrm{L} & \mathrm{R} & \mathrm{G} & \mathrm{G} & \mathrm{M}^{3} & \mathrm{Q} & \mathrm{I} & \mathrm{F} & \mathrm{V} & \mathrm{K} & \mathrm{T} & \mathrm{L} & \mathrm{T} & \mathrm{G} & \mathrm{K} & \mathrm{T} & \mathrm{I} & \mathrm{T} & \mathrm{L} & \mathrm{D} & \mathrm{V} & \mathrm{E} & \mathrm{P} & \mathrm{S} & \mathrm{D} & \mathrm{S} & \mathrm{I}\end{array}$ $530 \quad 550 \quad 570 \quad 590$

TCGACAACGTCAAGCAAAAAATTCAGGACAAGGAAGGCATCCCTCCTGACCAGCAGCGTCTGATCTTCGCTGGTAAGCAG

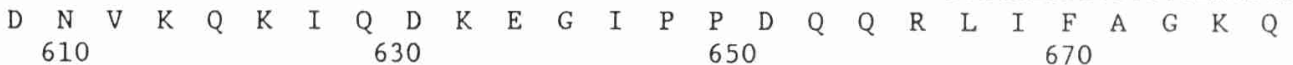

CTGGAGGACGGCCGCACGCTGAGCGACTACAACATCCAGAAGGAGTCAACGCTTCACCTGGTGCTTCGCCTGGGTGGCGG

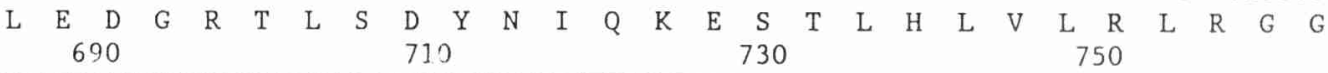
TAACTAAATTGGTTCAACGGTAAGGTCGTTTTTTCTTGCCTCGGACCAGTTTGTTTCGCTACTTAATGCTACTTTAAAGA $\mathrm{N} *$ $\begin{array}{lrr}770 & 790 & 810\end{array}$ AGTTTTAGTAGTATGAAGTGCAATCGATTACTCAATTAAAATGTTTCGACTTCAGAGCTGAATACTACTGGTAGTTATAT 850

870

CAATTTTGTGACATCGGCATCCTACGATGGAT

Fig. 2. Nucleotide sequence of the Phytophthora infestans polyubiquitin gene (ubi3R) and corresponding amino acid sequence of the encoded protein. The transcription start site as determined by primer extension is indicated by an asterisk. Numbered methionine residues in the amino acid sequence represent the start of the three ubiquitin units. Underlined nucleotides in the 5 ' non-coding region match the consensus sequence for heat shock promoter elements (CNNGAANNTTCNNG [4]). Overlined DNA sequence (AATTAAAA) in the $3^{\prime}$-flanking region of the polyubiquitin gene represents a possible polyadenylation signal. 
summarized in Fig. 1. An open reading frame of $687 \mathrm{nt}$ containing three almost identical $228 \mathrm{nt}$ repeats was found in the $1632 \mathrm{nt}$ sequence (Fig. 2). Comparison of the $687 \mathrm{nt}$ sequence with the sequence databank revealed that the sequence codes for polyubiquitin. The coding region of the polyubiquitin gene encodes three ubiquitin units with a length of 76 amino acids in a head-to-tail arrangement followed by an extra asparagine residue at the carboxy-terminal end. Although the ubiquitin-coding repeats within the gene differ by up to 8 out of $228 \mathrm{bp}$, they code for identical amino acid sequences (Fig. 2)). Only 4 or 5 amino acids of the 76 amino acid ubiquitin sequence differ from the sequence of barley, human, chicken and yeast ubiquitin (Fig. 3). Because of the three ubiquitin repeated units we have designated the gene $u b i 3 R$.

In order to map the $5^{\prime}$ end of the ubi3R transcript, primer extension was performed on poly(A) ${ }^{+}$RNA isolated from the fungus grown in vitro and from uninfected potato leaves using an oligonucleotide complementary to the $u b i 3 R$ sequence at positions -2 to -19 relative to the ATG start codon to prime the synthesis reaction. The primer extension products were electrophoresed next to the products of a sequencing reaction using the same oligonucleotide as primer and
pUB-S as template DNA. Figure 4 shows a primer extension product of 51 nucleotides indicating that the transcription initiation site of $u b i 3 R$ is located at position -52 relative to the ATG start codon.

As in most fungal genes, no typical 'TATAA' or 'CAAT' boxes are present in the promoter region. Several CT-rich regions, commonly found in the vicinity of the initiation codons of fungal genes, are present upstream of the ATG start codon. Similarities matching the consensus sequence for heat shock promotor elements [4] which have been shown to be present in polyubiquitin genes from a number of organisms, were also found in the $5^{\prime}$ non-coding region of the $u b i 3 R$ gene (underlined in Fig. 2). In the 3'flanking region of the gene, a possible polyadenylation recognition sequence (AATTAAAA) was found at position +797 to $+804,107 \mathrm{nu}-$ cleotides downstream of the TAA stop codon (overlined in Fig. 2).

The identified ubiquitin gene is a member of a multigene family

Northern blot analysis of RNA isolated from the in vitro grown mycelium, using the two $228 \mathrm{bp}$

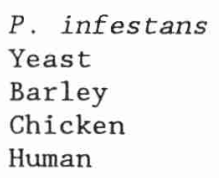

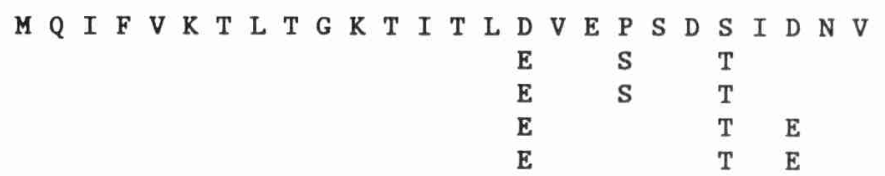

Fig. 3. Amino acid sequence comparison between the last ubiquitin encoding unit (77 amino acids) of Phytophthora infestans polyubiquitin and the last ubiquitin-encoding unit of polyubiquitin of yeast [35], barley [17], chicken [6] and human [2]. Only amino acid residues which differ from the $P$. infestans sequence are shown in the yeast, barley, chicken and human amino acid sequence. 


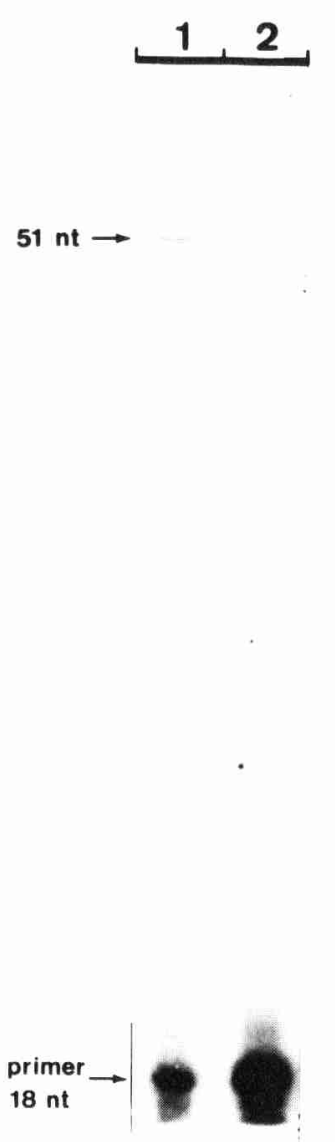

Fig. 4. Primer extension of $3 \mu \mathrm{g}$ of poly(A) ${ }^{+}$RNA isolated from in vitro grown Phytophthora infestans mycelium (lane 1) and non-infected potato leaves (lane 2$)$ using a primer (5'GTTGCCTCGGTTTATGAG-3') complementary to the $u b i 3 R$ sequence at position -2 to -19 .

$P v u$ II fragments from the coding region of $u b i 3 R$ as probe, shows four bands of ca. 850,1100, 1350 and 2350 nucleotides (Fig. 5A, lane 5). Longer exposure reveals a fifth band of circa 1850 nucleotides just above the plant ubiquitin mRNA. This suggests that the genome of $P$. infestans contains multiple copies of ubiquitin-encoding genes of different lengths. Using the gene-specific probe from the $u b i 3 R$ promotor region, it was shown that the 850 nucleotide transcript corresponds to the $u b i 3 R$ gene (Fig. 5B). Southern blot analysis of digested genomic DNA in which the two $228 \mathrm{bp}$ $P v u$ II fragments from the $u b i 3 R$ coding region were used as a probe (Fig. 6), confirmed that the

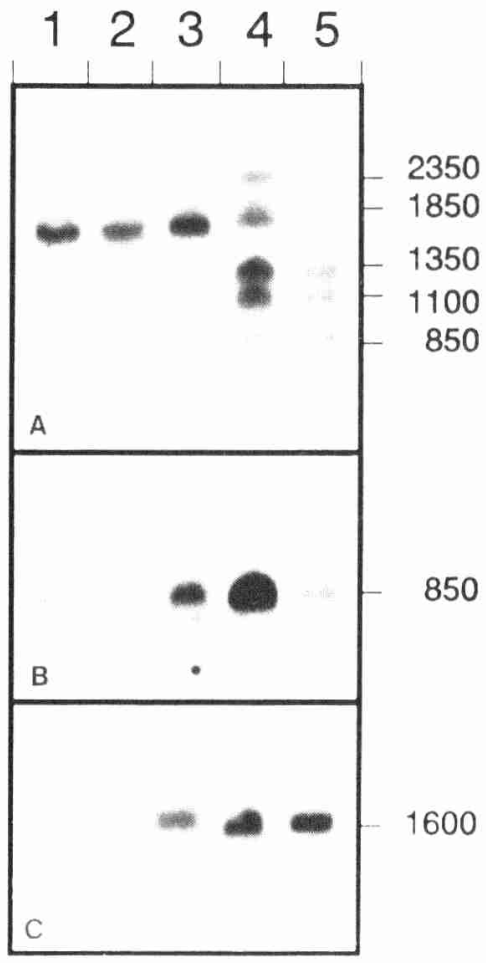

Fig. 5. Northern blot analysis of $15 \mu \mathrm{g}$ of total RNA isolated from uninfected potato leaves (lane 1), colonized potato leaves, 1 day after inoculation (lane 2), 2 days after inoculation (lane 3 ) and 3 days after inoculation (lane 4 ) and from Phytophthora infestans grown in vitro (lane 5). The two $228 \mathrm{bp}$ $P v u$ II fragments from the $u b i 3 R$-coding region (A), the $u b i 3 R$ gene-specific probe from the promoter region of $u b i 3 R(\mathrm{~B})$ and the $2.8 \mathrm{~kb}$ Pst $\mathrm{I}$ insert from pSTA31 containing the $P$. infestans actin $(a c t A)$ gene $(\mathrm{C})$ were used as probes.

identified ubiquitin gene belongs to a multigene family. In each digest analysed, multiple bands hybridize. Among those a $2.3 \mathrm{~kb}$ Hind III band, a $3.2 \mathrm{~kb}$ Sst I band and a $5.3 \mathrm{~kb} K p n$ I band correspond to identical restriction fragments in the DNA of phage DHC1 (Fig. 1). The Eco RI and the Bam HI fragment on the Southern blot differ in size with those in the phage DHC1 because only a part of these fragments is linked to vector DNA. Since the coding region of $u b i 3 R$ does not have any internal Kpn I, Eco RI, Bam HI, Hin$\mathrm{d}$ III and Sst I sites and no introns it is evident that the P. infestans genome contains multiple copies of ubiquitin-encoding genes. 


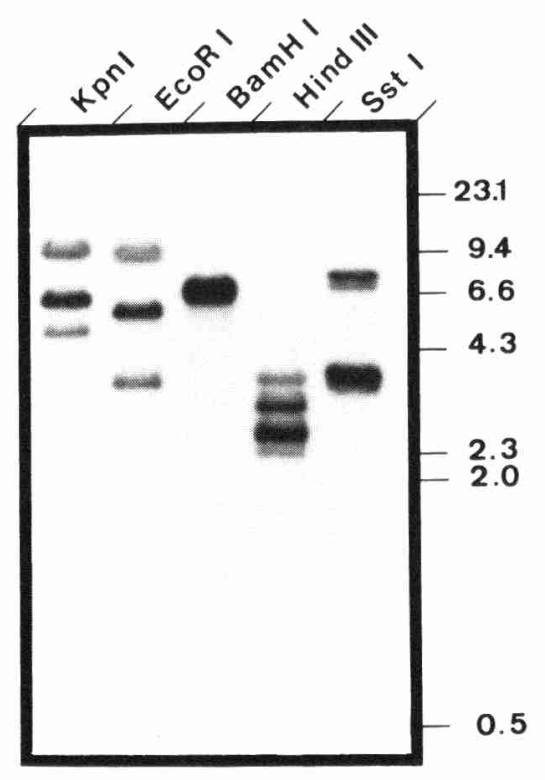

Fig. 6. Southern blot analysis of Phytophthora infestans DNA ( $10 \mu \mathrm{g} /$ lane) digested with the restriction enzymes indicated. The two 228 bp $P v u$ II fragments from the coding region of $u b i 3 R$ were used as probe.

In planta induced expression of Phytophthora infestans ubiquitin genes

The differential expression of the characterized ubiquitin gene was confirmed in two ways. In the first procedure interaction RNA, i.e. RNA isolated from inoculated leaves, and RNA isolated from mycelium grown in vitro was subjected to northern blot analysis (Fig. 5). Equal amounts of interaction RNA and fungal RNA were applied to the gel. The hybridization signals of the ubiquitin probe with interaction RNA (Fig. 5A, lane 4, 3 days after inoculation) are 2-3 fold stronger in comparison with the signals obtained with RNA isolated from the fungus grown in vitro (Fig. 5A, lane 5) indicating that the relative amounts of all fungal ubiquitin transcripts is higher in interaction RNA. The $1800 \mathrm{nt}$ transcript present in lanes $1-4$ of Fig. $5 \mathrm{~A}$ is a potato ubiquitin messenger. Due to the highly conserved sequence of ubiquitin, the potato ubiquitin transcript is crosshybridizing with the fungal ubiquitin probe. To follow the progression of fungal growth during the development of the disease, the proportion of fun- gal RNA in the total RNA population isolated from infected leaves was determined. To this end a probe of the constitutively expressed actin $(a c t A)$ gene of $P$. infestans [46] was used for hybridization of the northern blot (Fig. 5C). One day after inoculation the proportion of fungal RNA in the interaction RNA is very low. Due to the increasing amount of fungal biomass during colonization of the leaf tissue, the proportion of fungal RNA in the interaction RNA mixture increases rapidly to ca. $50 \%$, three days after inoculation. Taking this into consideration, the results of the northern blot analyses show that the expression of the ubiquitin encoding genes during growth of the fungus in planta increases 4-6-fold. Using a $u b i 3 R$ gene-specific probe, the induction of expression of the $u b i 3 R$ gene seems to be even higher (Fig. 5B).

In the second procedure the difference in relative abundance of $P$. infestans ubiquitin mRNAs in planta and in vitro was analysed by comparative hybridization of four replica filters of the $P$. infestans genomic library with (1) the random primer labelled $228 \mathrm{bp} P v u$ II fragments from the $u b i 3 R$ coding region (Fig. 7-U), (2) labelled interaction cDNA derived from poly $(\mathrm{A})^{+}$RNA of the interaction, 3 days after inoculation (Fig. 7-I), (3) labelled fungal cDNA made from poly $(\mathrm{A})^{+}$RNA of the fungus grown in vitro (Fig. 7-F) and (4) labelled cDNA derived from poly $(\mathrm{A})^{+}$RNA of uninfected potato leaves (Fig. 7-P) as a control. Lambda clones containing ubiquitin encoding sequences (indicated by arrows in Fig. 7) gave rise to a relatively strong signal when hybridized with labelled interaction cDNA (Fig. 7-I). Hybridization of a control replica filter with labelled cDNA derived from poly $(\mathrm{A})^{+}$RNA of uninfected potato leaves (Fig. 7-P) shows very weak or no signals indicating that the signals in Fig. 7-I are predominantly due to hybridization with fungal cDNA. Since the intensity of the signal is positively correlated with the abundance of the corresponding mRNAs, the ubiquitin mRNAs can be classified as highly abundant in the $P$. infestans mRNA population of the interaction. Hybridization of a replica filter with labelled fungal cDNA (Fig. 7-F) shows a relatively weak signal of the same clones 


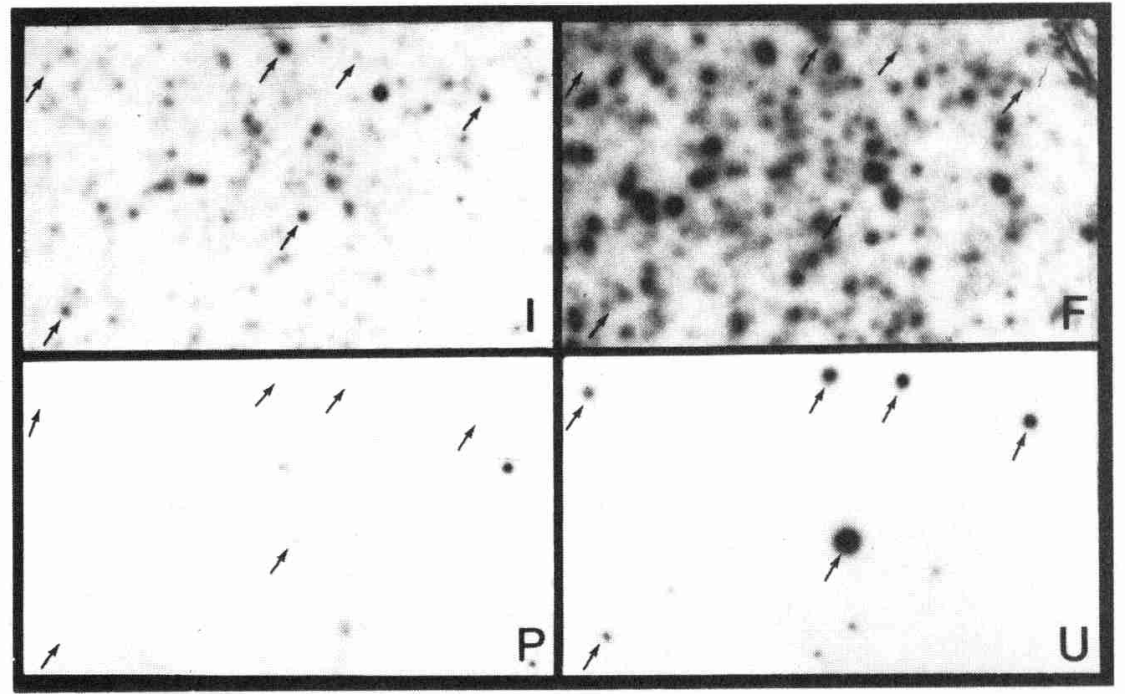

Fig. 7. Comparative hybridization of four replica filters of the Phytophthora infestans genomic library. Filters were hybridized with equal amounts of labelled interaction cDNA derived from poly $(\mathrm{A})^{+}$RNA of the interaction, 3 days after inoculation (I), labelled cDNA derived from poly $(\mathrm{A})^{+}$RNA of in vitro grown $P$. infestans mycelium (F), labelled cDNA derived from poly $(\mathrm{A})^{+}$RNA of uninfected potato leaves (P) and the two 228 bp $P v u$ II fragments from the ubi3R-coding region labelled by random primer labelling $(\mathrm{U})$.

indicating that ubiquitin mRNAs are several-fold less abundant in the mRNA population of in vitro grown mycelium than in the mRNA population of in planta produced mycelium. This procedure even underestimates the difference in abundance of the ubiquitin mRNAs because the filters were hybridized with equal amounts of labelled cDNA whereas the proportion of fungal cDNA in the interaction cDNA probe is approximately half of that in the fungal cDNA probe.

\section{Discussion}

Differential hybridization of cDNA libraries has been proved to be a useful tool for the isolation of genes which are differentially expressed under distinct physiological conditions, in particular for the isolation of developmentally regulated genes [43, 44]. Differential hybridization of genomic libraries is not often utilized since large vector inserts and low specificity of the labelled cDNA probes make it difficult to map and isolate the genes of interest. Isolation of in planta induced genes from $P$. infestans can only be done by differential screening of a genomic library since the use of a cDNA library made from interaction poly $(\mathrm{A})^{+}$RNA will yield both differentially expressed plant and fungal genes which cannot directly be distinguished. In developing the procedure using a genomic library it was of utmost importance to use cDNA probes with a high specific activity $\left(>10^{8} \mathrm{cpm} / \mu \mathrm{g}\right.$ cDNA) to be able to isolate putative in planta induced genes from the $P$. infestans genomic library.

Using the procedure described above a differentially expressed $P$. infestans polyubiquitin was isolated from a genomic library. The structure of the selected $u b i 3 R$ gene is completely consistent with the unique structure of known polyubiquitin genes from other organisms $[23,30]$. The characterized gene consists of three repeats each coding for the 76 amino acid ubiquitin peptide. Southern and northern blot analyses showed that the characterized polyubiquitin gene is a member of a multigene family. The $u b i 3 R$ gene codes for 
the $850 \mathrm{nt}$ transcript as shown in Fig. 5B. The sizes of the other transcripts $(1100,1350,1850$ and $2350 \mathrm{nt}$ ) indicate that they may code for polyubiquitin genes containing up to $4,5,7$ and 9 ubiquitin units which is a common feature for polyubiquitin gene families.

Ubiquitin is one of the most conserved proteins known to date (for reviews see $[13,22,23,30$, $36])$. The 76 amino acid protein occurs in all eucaryotic cells, either free or covalently attached to proteins in the cytosol, plasma membrane or to chromosomal histones. Ubiquitin has been shown to play a key role in several important cellular processes such as the selective degradation of intracellular proteins $[22,23,36]$, maintenance of chromatin structure $[29,31]$, regulation of gene expression $[3,18]$ and modification of cell surface receptors $[26,40,50]$. Genes encoding ubiquitin have been characterized for a variety of organisms such as yeast [35], man [47], chicken [6], Xenopus laevis [11], Drosophila melanogaster [1], Tripanosoma cruzi [42] and Caenorhabditis elegans [19]. In each case, ubiquitin is encoded by one or more polyubiquitin genes which consist of direct repeats of the 76 amino acid coding units. The least repeat at the $3^{\prime}$ end of the polyubiquitin gene is usually followed by an extra amino acid residue which is not conserved among different species. In the $P$. infestans ubi3R gene this appears to be an asparagine. Although the unique structure of polyubiquitin genes has been conserved in evolution, considerable variation exists in the number of repeats within each polyubiquitin gene and the number of polyubiquitin encoding loci in the genome.

Recently another class of genes which contain the ubiquitin-coding sequence has been identified. In these genes the ubiquitin coding region is fused in frame to the $5^{\prime}$ end of a coding sequence of an unrelated polypeptide [33, 35, 37]. Their products are called ubiquitin carboxyl extension proteins (UbCEPs) and have been found in several eucaryotic organisms. The carboxyl extension proteins (CEPs) are reported to be ribosomal proteins whose fusion to ubiquitin is shown to facilitate ribosomal biogenesis [12]. Like the ubiquitin-encoding sequence, the CEP-encoding sequence of these natural gene fusions is conserved among species.

The expression of both classes of ubiquitin genes is found to be differentially regulated under conditions of stress, rapid cell growth or during development [17,34]. Induced expression of polyubiquitin genes by heat shock or other types of stress has been observed in a number of organisms [7, 32, 35]. This facilitates an increased production of ubiquitin monomers for the ubiquitin-mediated degradation of abnormal proteins which arise during stress. The expression of UbCEP-encoding genes has been demonstrated to be induced under conditions of rapid cell growth and cell division [30, 35, 42]. As protein synthesis is a major cellular process during cell growth and CEPs are identified as ribosomal proteins, the significance of induced expression of UbCEP encoding genes is obvious.

The induced expression of ubiquitin-encoding genes in $P$. infestans during colonization of potato leaves may reflect the highly active metabolic state of the mycelium in the host tissue. During exponential growth in vitro on synthetic Henniger medium and on rich rye-sucrose agar medium, however, the mycelium is also in a highly active metabolic state but the ubiquitin-encoding genes show a 4-6-fold lower level of expression. This implies that the host environment specifically induces the expression of the ubiquitin-encoding genes. Which factors or conditions are due to the in planta induced expression of the $P$. infestans ubiquitin genes needs to be investigated. Also the significance of induced expression of the ubiquitin-encoding genes during pathogenesis remains to be resolved. In view of the regulatory function of ubiquitin in gene expression $[3,18]$ it is tempting to speculate that induction of the characterized $u b i 3 R$ gene may have an effect on the regulation of the expression of genes involved in pathogenicity. The other genes containing the ubiquitin-encoding sequence may code for polyubiquitin as well and may have a similar function, but it cannot be excluded that they encode UbCEPs and are involved in biogenesis of ribosomes.

Expression studies should reveal whether the 
ubiquitin genes are inducible in vitro by heat shock and stress or by particular plant factors in order to gain more insight into the significance of the induced expression of the $P$. infestans ubiquitin genes in planta. The $u b i 3 R$ gene is one of the first genes isolated from $P$. infestans and is highly expressed in vitro. The promoter region of the gene will be used for the construction of vectors for transformation of $P$. infestans, a necessary tool for the accomplishment of our goal, the isolation and characterization of pathogenicity genes of $P$. infestans.

\section{Acknowledgements}

We wish to thank Dr S.E. Unkles and Dr J.R. Kinghorn for the gift of the plasmid pSTA31 and Dr J.A.L. van Kan, Dr S.W. Ellis and Dr Ir F.P. M. Govers for critical reading and helpful comments on the manuscript.

\section{References}

1. Arribas C, Sampedro J, Izquierdo M: The ubiquitin genes in D. melanogaster: Transcription and polymorphism. Biochim Biophys Acta 868: 119-127 (1986).

2. Baker RT, Board PG: The human ubiquitin gene family: structure of a gene and pseudogenes from the Ub B subfamily. Nucl Acids Res. 15: 443-463 (1987).

3. Barsoum J, Varshavsky A: Preferential localization of variant nucleosomes near the $5^{\prime}$-end of the mouse dihydrofolate reductase gene. J Biol Chem 260: 7688-7697 (1985).

4. Bienz M, Pelham HRB: Mechanisms of heat-shock gene activation in higher eukaryotes. Adv Genet 24: 31-72 (1987).

5. Bilofsky HS, Burks C, Fickett JW, Goad WB, Lewitter FI, Rindone WP, Swindell CD, Tung CS: The GeneBank genetic sequence data bank. Nucl Acids Res 14: 1-4 (1986).

6. Bond U, Schlesinger MJ: The chicken ubiquitin gene contains a heat shock promoter and expresses an unstable mRNA in heat-shocked cells. Mol Cell Biol 6: 4602-4610 (1986).

7. Bond U, Schlesinger MJ: Ubiquitin is a heat shock protein in chicken embryo fibroblasts. Mol Cell Biol 5: 949 959 (1985).

8. Caten CE, Jinks JL: Spontaneous variability of single isolates of Phytophthora infestans. I. Cultural variation. Can J Bot 46: 329-347 (1968).
9. Coolbear T, Threlfall DR: A comparison of the sites of phytoalexin accumulation and of biosynthetic activity in potato tuber tissue inoculated with biotic elicitors. Phytochemistry 24: 2219-2224 (1985).

10. Cuypers B, Schmelzer E, Hahlbrock K: In situ localization of rapidly accumulated phenylalanine ammonia-lyase mRNA around penetration sites of Phytophthora infestans in potato leaves. Mol Plant-Microbe Interactions 1: 157 160 (1988).

11. Dworkin-Rastl E, Shrutkowski A, Dworkin MB: Multiple ubiquitin mRNAs during Xenopus laevis development contain tandem repeats of the 76 amino acid coding sequence. Cell 39: 321-325 (1984).

12. Finley D, Barte B, Varshavsky A: The tails of ubiquitin precursors are ribosomal proteins whose fusion to ubiquitin facilitates ribosome biogenesis. Nature 338: 394-401 (1989).

13. Finley D, Varshavsky A: The ubiquitin system: Functions and mechanisms. Trends Biochem Sci 10: 343-347 (1985).

14. Frischauf A-M: Construction and characterization of a genomic library in $\lambda$. In: Berger SL, Kimmel AR (eds) Methods in Enzymology vol 152: Guide to Molecular Cloning Techniques, pp. 190-199. Academic Press, San Diego, CA (1987).

15. Frischauf A-M, Lehrach H, Poustka A, Murray N: Lambda replacement vectors carrying polylinker sequences. J Mol Biol 170: 827-842 (1983).

16. Fritzemeier KH, Cretin C, Kombrink E, Rohwer F, Taylor J, Scheel D, Hahlbrock K: Transient induction of phenylalanine ammonia-lyase and 4-coumarate: $\mathrm{CoA}$ ligase mRNAs in potato leaves infected with virulent and avirulent races of Phytophthora infestans. Plant Physiol 85: 34-41 (1987)

17. Gausing K, Barkardottir R: Structure and expression of ubiquitin genes in higher plants. Eur J Biochem 158: 5762 (1986).

18. Goldknopf IR, Wilson G, Ballal NR, Busch H: Chromatin conjugate protein A24 is cleaved and ubiquitin is lost during chicken erythropoiesis. J Biol Chem 255: $10555-$ 10558 (1980).

19. Graham RW, Van Doren K, Bektesh S, Candido EPM: Maturation of the major ubiquitin gene transcript in Caenorhabditis elegans involves the acquisition of a trans-spliced leader. J Biol Chem 263: 10415-10419 (1988).

20. Hamm GH, Cameron GN: The EMBL data library. Nucl Acids Res 14: 5-10 (1986).

21. Henniger H: Versuche zur Kultur verschiedener Rassen von Phytophthora infestans (Mont) de By. auf künstlichen Nährböden. Phytopathol Z 34: 285 (1959).

22. Hershko A: Ubiquitin-mediated protein degradation. J Biol Chem 263: 15237-15240 (1988).

23. Hershko A, Ciechanover A: The Ubiquitin pathway for the degradation of intracellular proteins. Prog Nucl Acid Res Mol Biol 33: 19-56 (1986). 
24. Innes RW, Kuempel PL, Plazinski J, Cante-Cremers H, Rolfe BG, Djordjevic MA: Plant factors induce expression of nodulation and host-range genes in Rhizobium trifolii. Mol Gen Genet 201: 426-432 (1985).

25. Kombrink E, Schröder M, Hahlbrock K: Several 'pathogenesis-related' proteins in potato are 1.3- $\beta$ glucanase and chitinase. Proc Natl Acad Sci USA 85: 782-786 (1988).

26. Leung DW, Spencer SA, Cachianes G, Hammonds RG, Collings C, Henzel WJ, Barnard R, Waters MJ, Wood WI: Growth hormone receptor and serum binding protein: Purification, cloning and expression. Nature 330: 537-543 (1987).

27. Logemann J, Schell J, Willmitzer L: Improved method for the isolation of RNA from plant tissues. Anal Biochem 163: 16-20 (1987).

28. Maniatis T, Fritsch EF, Sambrook J: Molecular Cloning: A Laboratory Manual. Cold Spring Harbor Laboratory Press, Cold Spring Harbor, NY (1982).

29. Matsui SI, Seon BK, Sandberg AA: Disappearance of a structural chromatin protein A24 in mitosis: Implications for molecular basis of chromatin condensation. Proc Natl Acad Sci USA 76: 6386-6390 (1979).

30. Monia BP, Ecker DJ, Crooke ST: New perspectives on the structure and function of ubiquitin. Bio/technology 8 : 209-215 (1990).

31. Mueller RD, Yasuda H, Hatch CL, Bonner WM, Bradbury EM: Identification of ubiquitinated histones $2 \mathrm{~A}$ and 2B in Physarum polycephalum: Disappearance of these proteins at metaphase and reappearance at anaphase. J Biol Chem 260: 5147-5153 (1985).

32. Muller-Taubenberger A, Hagmann J, Noegel A, Gerisch G: Ubiquitin gene expression in Dictyostelium is induced by heat and cold shock, cadmium, and inhibitors of protein synthesis. J Cell Sci 90: 51-58 (1988).

33. Muller-Taubenberger A, Westphal M, Jaeger E, Noegel A, Gerisch G: Complete cDNA sequence of a Dictyostelium ubiquitin with a carboxy-terminal tail and identification of the protein using an anti-peptide antibody. FEBS Lett 229: 273-278 (1988).

34. Ohmachi T, Giorda R, Shaw DR, Ennis HL: Molecular organization of developmentally regulated Dictyostelium discoideum ubiquitin cDNAs. Biochemistry 228: 52265231 (1989).

35. Ozkaynak E, Finley D, Solomon M-J, Varshavsky A: The yeast ubiquitin genes: A family of natural gene fusions. EMBO J 6: 14.29-1439 (1987).

36. Rechsteiner M: Ubiquitin-mediated pathways for intracellular proteolysis. Ann Rev Cell Biol 3: 1-30 (1987).

37. Salveson G, Lloyd C, Farley D: cDNA encoding a human homolog of yeast ubiquitin 1. Nucl Acids Res 15: 54855486 (1987).
38. Sanger F, Nicklen S, Coulson AR: DNA sequencing with chain-terminating inhibitors. Proc Natl Acad Sci USA 74: 5463-5467 (1977).

39. Sargent TD: Isolation of differentially expressed genes. In: Berger SL, Kimmel AR (eds) Methods in Enzymology vol 152: Guide to Molecular Cloning Tecniques, pp. 423-432. Academic Press, San Diego, CA (1987).

40. Siegelman M, Bond MW, Gallatin WM, St. John T, Smith HT, Fried VA, Weissman IL: Cell surface molecule associated with lymphocyte homing is a ubiquitinated branched-chain glycoprotein. Science 231: 823-829 (1986).

41. Stachel SE, Nester EW, Zambryski PC: A plant cell factor induces Agrobacterium tumefaciens vir gene expression. Proc Natl Acad Sci USA 83: 379-383 (1986).

42. Swindle J, Ajioka J, Eisen H, Sanwal B, Jacquemot C, Browder Z, Buck G: The genomic organization and transcription of the ubiquitin genes of Trypanosoma cruzi. EMBO J 7: 1121-1127 (1988).

43. Timberlake WE: Developmental gene regulation in Aspergillus nidulans. Dev Biol 78: 497-510 (1980).

44. Timberlake WE: Isolation of stage- and cell-specific genes from fungi. In: Bailey JA (ed) Biology and Molecular Biology of Plant-Pathogen Interactions, pp.343-357. Springer-Verlag, Berlin/Heidelberg (1986).

45. Tooley PW, Therriën CD: Cytophotometric determination of the nuclear DNA content of 23 Mexican and 18 non-Mexican isolates of Phytophthora infestans. Exp Mycol 11: 19-26 (1987).

46. Unkles SE, Moon RP, Hawkins AR, Duncan J, Kinghorn JR: Actin in the oomycetous fungus Phytophthora infestans is the product of several genes. Gene, in press (1991).

47. Wiborg O, Pedersen MS, Wind A, Berglund LE, Marcker KA, Vuust J: The human ubiquitin gene family: Some genes contain multiple directly repeated ubiquitin coding sequences. EMBO J 4: 755-759 (1985).

48. Woloshuk CP, Kolattukudy PE: Mechanism by which contact with plant cuticle triggers cutinase gene expression in the spores of Fusarium solani f. sp. pisi. Proc Natl Acad Sci USA 83: 1704-1708 (1986).

49. Wyman AR, Wertman KF, Barker D, Helms C, Petri WH: Factors which equalize the representation of genome segments in recombinant libraries. Gene 49: $263-$ 271 (1986).

50. Yardin Y, Escobedo JA, Kuang W-J, Fang-Ferng TL, Daniel TO, Tremble PM, Cheng EY, Ando ME, Harkins RN, Francke U, Fried VA, Ullrich A, Williams LT: Structure of the receptor for platelet derived growth factor helps define a family of closely related growth factor receptors. Nature 323: 226-232 (1986). 